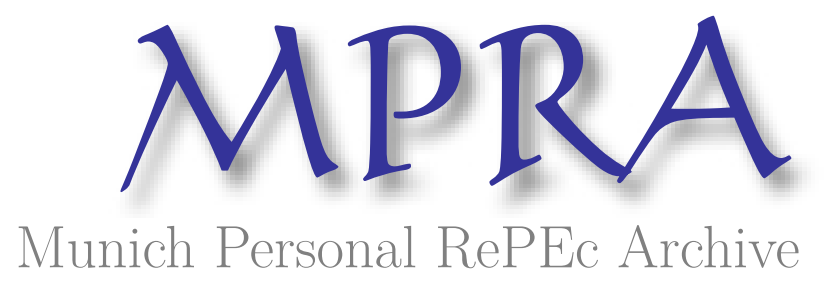

\title{
Efficiency of Micro Finance Institutions in India: A Stochastic Distance Function Approach
}

Kumar, Nitin and Sensarma, Rudra

July 2017

Online at https://mpra.ub.uni-muenchen.de/81064/

MPRA Paper No. 81064, posted 31 Aug 2017 16:27 UTC 


\title{
Efficiency of Micro Finance Institutions in India: A Stochastic Distance Function Approach
}

\author{
Nitin Kumar \\ Reserve Bank of India \\ Centre 1, World Trade Centre, Cuff Parade, Mumbai, 400005 \\ Email: nitin.005us@gmail.com \\ Rudra Sensarma (Corresponding author) \\ Indian Institute of Management Kozhikode \\ Kunnamangalam, Kozhikode, Kerala, 673570 \\ Email: $\underline{\text { rsensarma@gmail.com }}$
}

\begin{abstract}
We examine the efficiency-outreach debate in the context of Indian Micro Finance Institutions (MFIs). We employ the stochastic distance function approach for 75 MFls during 2004-2011. We find that there are significant inefficiency effects but efficiency is improving over time. Among the determinants of inefficiency, average loan balance per borrower and number of women borrowers appear to improve efficiency. This suggests that the efficiency-outreach debate is more nuanced than is presented in the literature and depends on the way outreach is defined. Profitability, size and leverage seem to increase efficiency whereas age of the MFI is associated with higher inefficiency.

KEY WORDS: Micro Finance Institutions; Efficiency; Stochastic Distance Function

JEL Classification: G21; C51; C33
\end{abstract}




\section{Efficiency of Micro Finance Institutions in India: A Stochastic Distance Function Approach}

\section{Introduction}

In developing countries the reach of financial intermediaries is greater in urban areas and limited in rural or informal markets even though the latter comprise a vast segment of the economies. For instance in India more than two-thirds of the population dwells in rural agglomerations with agriculture being the major occupation. Rajan (2014) points out that despite much financial inclusion efforts by policy makers, very few among the target population have been reached and huge potential of enabling factors such as technology is yet to be exploited. Socio-economic features of backward areas make it financially nonviable for banks to set up their branches among populations with low or nil incomes leading to financial exclusion (Kumar, 2012; Kumar, 2013).

It is in this context that the role of Micro Finance Institutions (MFIs) is important in rendering financial access to rural sections and near poor households. However, the literature on MFIs has pointed out that focus on financial sustainability may lead to dilution of outreach (Hermes and Lensink, 2011). The argument goes that the poor cannot be helped in the long run if the MFIs are not financially sustainable or efficient. However the quest for efficiency may lead to a focus on wealthier clients and compromise on the outreach goals of MFls - lending to the poor and women - a phenomenon known as "mission drift" (Cull et al, 2007). Hermes et al. (2011) examined the tradeoff between efficiency and outreach by estimating efficiency of MFIs using stochastic frontier analysis (SFA). Using a cross-country sample of 435 MFIs, they found that there is a tradeoff between efficiency and outreach whereby those institutions that have lower average loan size and lend more to women are less efficient. Cull et al (2007) had reported similar findings. In this paper we analyze data from the world's largest microfinance market, viz. India and study efficiency of Indian MFIs. Our main objectives are to estimate efficiency using the stochastic distance function approach (which has not been used before in this literature) and to analyze the determinants of efficiency. In doing so we try to ascertain whether there is a tradeoff between efficiency and outreach (measured by average loan size and number of women borrowers).

MFIs have been successfully serving the poor in many transition economies. The Grameen Bank in Bangladesh as pioneered by Muhammad Yunus has served numerous rural poor with women being the major beneficiaries. It was set up on a joint liability principle in which a group of 5 to 10 members would jointly avail a loan and guarantee its repayment. Bank Rakyat Indonesia (BRI) is an example from Indonesia where it is one of the largest state-owned banks with an extensive branch network. BRI offers loans, voluntary savings products, fund transfer services as well as training and consulting services (Robinson, 2002). Examples of successful Microfinance have been noted in Latin America e.g. Banco Ademi has been one of the Latin America's first sustainable MFIs. Banco Sol is a Bolivia based MFI that bases its lending methodology on individual credit technology with minimum profit orientation. Peru based Mibanco was created in 1998 with the objective of assisting small and micro-businesses. It targets markets where demand for micro-credit is highest and supply weakest (Fernando, 2004). India has been a relatively late entrant to the microfinance model but has now become the world's largest microfinance market. As per 
reported information for the year 2013 (mixmarket.org), MFIs in India have disbursed loans to 31.3 million borrowers amounting USD 4.6 billion. Simultaneously, they have also mobilized savings of USD 36.4 million encompassing 50,116 depositors. Although the objectives and reach of MFIs in India have been reasonable, it is not without impediments. The absence of uniform regulation, over-indebtedness and poor operating procedures have contributed to failure and distress as observed in the Krishna crisis in Andhra Pradesh in 2010 where several MFIs collapsed after a period of rapid growth (Mader, 2013).

Efficiency can be studied by assessing how well a firm is able to utilize its resources to meet its output objectives. Consequently, we may define inefficiency as the extent by which a firm falls short in producing output vis-à-vis the most efficient firm in the same industry that uses the same level of inputs. There exists considerable literature analyzing the efficiency of MFIs across the globe that can be classified into two groups as per the methodology employed to measure efficiency. One strand has applied the parametric approach of SFA, where MFIs are assumed to be producing a single output which becomes the dependent variable of the estimable production function (Hermes et al., 2011; Servin et al., 2012). A restriction of standard SFA methodology is that it is unable to handle more than one dependent variable. Other studies have employed the non-parametric and deterministic approach of Data Envelopment Analysis (DEA) that is capable of handling multiple outputs (Haq et al., 2010; Masood \& Ahmad, 2010). However, DEA has the limitation of not being able to provide tests of significance of the efficiency estimates. The stochastic distance function approach strikes a compromise between the above two frequently used methods by incorporating multiple outputs in the production function and at the same time allowing tests of significance. ${ }^{1}$ To the best of our knowledge, ours is the first study to analyze MFI efficiency by employing the stochastic distance function approach. Utilizing an unbalanced panel of 75 MFIs from 2004 to 2011 our findings point to significant inefficiency effects that have risen sharply over last few years. Among the determinants of inefficiency, we find that average loan balance per borrower, number of women borrowers, size and profitability appear to enhance MFI efficiency. On the other hand, age of the MFI is associated with lower efficiency.

This paper makes several contributions to the microfinance literature. This is the first study to use the stochastic distance function approach to analyze MFIs which helps us to overcome the drawbacks of the much used SFA and DEA methods. Second, we estimate efficiency of MFIs based on a large panel data from India which is the largest microfinance market in the world. ${ }^{2}$ Finally, we contribute to a key debate in the microfinance literature over efficiency versus outreach by pointing out that this tradeoff is more nuanced than is usually perceived as the relationship between the two depends on the way outreach is measured. The rest of the paper is organized as follows. The database and variables are described in Section 2 followed by econometric model and methodology discussed in Section 3. The results are reported in Section 4 with the concluding remarks and summary presented in Section 5.

\footnotetext{
${ }^{1}$ This method was originally suggested by Shephard (1970). Recently the banking literature has started using it to estimate efficiency of commercial banks e.g. Cuesta and Orea (2002) use it to analyze Spanish banks; Das and Kumbhakar (2012) employ it for a study of Indian banks.

${ }^{2}$ Masood and Ahmad (2010) study Indian MFIs but with a much smaller panel of 40 institutions over 4 years and use the SFA methodology. Moreover they do not comprehensively address the sustainability-outreach debate.
} 


\section{Data source and key variables}

The information for the existing analysis is obtained from the publicly available Microfinance Information Exchange (MIX) Network ${ }^{3}$. It is a repository of comprehensive quality information on more than $2000 \mathrm{MFIs}$ across the globe and has been used by many published studies such as Ahlin et al. (2011) and Tchakoute (2010). We used this website to gather a comprehensive panel of Indian MFIs. At the outset we included only those MFIs that have quality audited information. As per MIX database such firms are ranked with at least four diamonds ${ }^{4}$. Such filtering is expected to provide a reliable dataset for valid analysis. The next stage comprises of setting the initial year of the panel. As the number of MFIs available from 2004 onwards improves significantly, we set 2004 as the initial year for the study. Thus, the final dataset is an unbalanced panel encompassing 75 MFIs from 2004 to 2011. The monetary variables as per MIX database are available in terms of US dollars. In order to interpret results in terms of local currency they are converted to Indian Rupees and treated in real terms by deflating with the Wholesale Price index.

Next, we select the set of output and input variables. As per the production function approach (Benston, 1965), financial institutions are considered as providers of service to customers with physical variables i.e. labour, material, information system as the inputs and number of loan and deposit accounts as output. Alternately, intermediation function approach (Berger and Humphrey, 1992) regards them as intermediaries between depositors and borrowers with operating and interest expenses as inputs, loans and other major assets count as outputs. The difference between the two approaches essentially boils down to whether or not deposits are considered as output. Since MFIs are essentially credit providers, the production approach, where deposits are output, may not be appropriate. Therefore we follow the intermediation approach. MFIs have to cater to marginalized masses and the same time take care of financial viability of the business. In such a scenario, the number of borrowers and amount lent along with financial revenues are important factors for consideration as output. Labour is an input along with expenses. Expenses characteristics are classified separately into operating (primarily on personnel, depreciation, administrative) and financial expense (such as interest and fee of associated liability).

To summarize, the output variables chosen are financial revenue $\left(y_{1}\right)$, gross loan portfolio $\left(y_{2}\right)$ and number of active borrowers $\left(y_{3}\right)$. The number of personnel $\left(x_{1}\right)$, operating expenses $\left(x_{2}\right)$ and financial expenses $\left(x_{3}\right)$ constitute the input variables. A wide array of factors has been selected as determinants of inefficiency. These include the key outreach variables of average loan balance per borrower (ALB) and the number of active women borrowers (WB). This is intended to capture the key missions of MFIs that is to lend to the poor (showing up as low ALB) and to women clients. We control for size of the MFI using asset size (AST). Natural logarithm transformation has been applied for all these variables. Return on assets (ROA) is included among determinants as a control for profitability. Debt equity ratio is included as a measure of leverage. Age is included as years of operation since the year of establishment of the MFI. It is expected to account for learning or performance improvement over the years through experience. Additionally,

\footnotetext{
${ }^{3}$ www.mixmarket.org

${ }^{4}$ To portray the quality of data, MIX uses a diamond scale ranging from 1 to 5 . The highest diamond level indicates that the organization has supplied audited financial statements by third party and adjusted variables.
} 
time trend has been included to capture possible time effects. Finally certain environmental aspects have been captured by dummy variables as explained below.

Although, there is no uniform regulatory body for supervision of MFIs, there is some sector-specific regulation by the banking regulator the Reserve Bank of India (RBI) and local state governments. MIX database provides information whether a MFI is regulated or not. This dichotomous information is included as a possible efficiency determinant, viz., DUM (RGL) taking value unity in case the MFI is regulated and zero otherwise. Generally, MFIs operating in southern states are perceived to be more efficient. This hypothesis is tested by adding a dummy variable for MFIs based in southern states. The dummy variable DUM (LCN) takes the value unity for MFIs based in the southern states of Andhra Pradesh, Kerala, Karnataka and Tamil Nadu. The legal status of MFIs varies from Non-Banking Financial Institution, Bank, Credit Union to NGO. On one side where banks are strictly regulated and are free to accept public deposits, services of NGOs are of a more limited nature, usually not including deposit taking and with no supervision by the RBI. Thus, it makes sense to control for NGOs vis-à-vis other financial agencies with the legal status dummy DUM (LS) equal to unity for NGOs and zero otherwise.

\section{Model and methodology}

As explained earlier we use the stochastic output distance function approach. According to Cuesta and Orea (2002) this approach has the advantage that it allows modelling of multiple outputs and multiple inputs without requiring price information thereby making it adequate for analysis of financial services. The commonly used technique of SFA requires input price data for estimating cost frontier and output price data for estimating profit frontier. In the microfinance sector, output and input price data are either not available or not reliable due to absence of perfectly competitive market conditions. The other popular method is DEA which does not necessarily require price information. But DEA has the disadvantage that it does not allow for hypothesis testing unless a two-stage procedure is followed and the two-stage procedure suffers from severe econometric problems (Simar and Wilson, 2007). The stochastic distance function approach is able to overcome the limitations of both SFA and DEA. It has been previously used to study efficiency in a number of industries such as banking (Das and Kumbhakar, 2010), agriculture (Irz and Thirtle, 2004) and hospitals (Ferrari, 2006). This is the first paper that applies this methodology to estimate efficiency in the microfinance sector.

We follow Cuesta and Orea (2002) for the empirical specification. The general form of the stochastic output distance function is:

$1=D_{0}\left(y_{i t}, x_{i t}, \beta\right) h\left(\varepsilon_{i t}\right) ; \quad h\left(\varepsilon_{i t}\right)=\exp \left(u_{i}+\vartheta_{i t}\right)$

where $\vartheta_{i t}$ is the standard error term and $u_{i}$ is the inefficiency term following a half normal distribution such that $u_{i t}=\{\exp [-\eta(t-T)]\} u_{i}$

Imposing linear homogeneity and using translog function we obtain the following estimable regression: 


$$
\begin{aligned}
-\ln y_{N i t}=\alpha_{0} & +\sum_{k=1}^{M} \alpha_{k} \ln x_{k i t}+\sum_{j=1}^{N-1} \beta_{j} \ln y_{j i t}^{*}+\frac{1}{2} \sum_{k=1}^{M} \sum_{h=1}^{M} \alpha_{k h} \ln x_{k i t} \ln x_{h i t} \\
& +\frac{1}{2} \sum_{j=1}^{N-1} \sum_{h=1}^{N-1} \beta_{j h} \ln y_{j i t}^{*} \ln y_{h i t}^{*}+\sum_{k=1}^{M} \sum_{j=1}^{N-1} \rho_{k j} \ln x_{k i t} \ln y_{j i t}^{*}+\gamma_{0} t+\frac{1}{2} \gamma_{00} t^{2} \\
& +\sum_{k=1}^{M} \varphi_{k} t \ln x_{k i t}+\sum_{j=1}^{N-1} \tau_{j} t \ln y_{j i t}^{*}+\vartheta_{i t}-u_{i t}
\end{aligned}
$$

where,

$y_{j i t}^{*}=\frac{y_{j i t}}{y_{N i t}} ; j=1, \ldots, N-1$

Here $y_{j i t}$ represents $j$-th output of the $i$-th MFI at the $t$-th time point. The corresponding outputs for $j=$ $1,2,3$ are financial revenue $(F R)$, gross loan portfolio $(G L P)$ and number of active borrowers (NAB) respectively with $N A B$ arbitrarily chosen as numeraire to normalize outputs. Similarly, $x_{k i t}(k=1,2,3)$ denote inputs, viz., number of personnel $(N P)$, operating expenses $(O E)$ and financial expenses (FE) respectively; $t$ is time trend used as index of technology.

Since we are interested in analyzing the determinants of inefficiency, we follow Battese and Coelli (1995) to specify the inefficiency component $u_{i t}$ by truncation (at zero) of $N\left(\mu, \sigma_{u}^{2}\right)$ distribution and inefficiency modeled as:

$$
\mu_{i t}=z_{i t} \delta+\varepsilon_{i t}
$$

The vector of variables explaining inefficiency is depicted by $z_{i t}$; $\delta$ is the vector of parameters to be estimated and $\varepsilon_{i t}$ captures the standard noise term. The detailed inefficiency equation is specified as follows:

$$
\begin{array}{rl}
\mu_{i t}=\delta_{0}+\delta_{1} A & L B_{i t} \\
& +\delta_{2} W B_{i t}+\delta_{3} t+\delta_{4} A S T_{i t}+\delta_{5} R O A_{i t}+\delta_{6} D E R_{i t}+\delta_{7} A G E_{i t}+\delta_{8} D U M(R G L)_{i t} \\
& +\delta_{9} D U M(L C N)_{i t}+\delta_{10} D U M(L S)_{i t}+\varepsilon_{i t}
\end{array}
$$

Here, average loan balance per borrower is captured by $A L B_{i t}$ and the number of women borrowers by $W B_{i t}$. The variable $t$ captures time trend and $A S T_{i t}$ controls for MFI asset size. Profitability is measured by $R O A$. Other MFI specific variables are the debt equity ratio (DER), years of operation of MFI (AGE) and finally the three MFI specific dummy variables for regulation, location and legal status.

\section{Empirical results}

Before moving on to estimation results, a glance over the mean behavior of pertinent variables is useful (see Table 1). Average asset size swelled from USD 7.22 million per MFI in 2004 to USD 64.765 million in 2011 , about a nine fold increase over seven years. The mean size of loan portfolio per MFI has also marked consistent improvement from USD 6.213 million in 2004 to USD 57.057 million in 2011. The number of borrowers per MFI have increased six times for this period, from 55 thousand in 2004 to 367 thousand in 
2011. Among the borrowers, women borrowers have also shown marked improvement over time, albeit with a minor decline in 2011 compared to 2009. To supplement increased workload of MFls, staff strength has grown over the years to slightly more than one thousand per MFI in 2011. Both performance measures ROA and ROE (Return on Equity) depict erratic behavior with no clear trend. Debt equity ratio has fallen over the years from nearly 90 percent in 2004 to 7 percent in 2009 before reverting back to 29 percent in 2011. Capital asset ratio improved from 18 percent in 2004 to 25 percent in 2011 except for 2007 when it slipped to 16 percent.

Table 1: Average scores of key variables for selected years

\begin{tabular}{|c|c|c|c|c|c|c|}
\hline Year & Assets & $\begin{array}{l}\text { Financial } \\
\text { Revenue }\end{array}$ & $\begin{array}{r}\text { Gross Loan } \\
\text { Portfolio }\end{array}$ & $\begin{array}{r}\text { Number of } \\
\text { Active } \\
\text { Borrowers }\end{array}$ & Personnel & $\begin{array}{r}\text { Operating } \\
\text { Expenses }\end{array}$ \\
\hline 2004 & 7225789.05 & 1878669.83 & 6213546.62 & 55437.86 & 280.17 & 862731.23 \\
\hline 2007 & 30548746.46 & 6959286.08 & 24435544.7 & 179960.47 & 747.82 & 3014791.88 \\
\hline 2009 & 63637782.16 & 15735339.64 & 55363071.03 & 337878.29 & 1196.09 & 5226600.39 \\
\hline 2011 & 64764882.56 & 12579997.87 & 57057399.07 & 367369.6 & 1295.04 & 6042126.96 \\
\hline Year & $\begin{array}{l}\text { Financial } \\
\text { Expenses }\end{array}$ & $\begin{array}{c}\text { Women } \\
\text { Borrowers }\end{array}$ & ROA & ROE & $\begin{array}{r}\text { Debt Equity } \\
\text { ratio }\end{array}$ & $\begin{array}{r}\text { Capital Asset } \\
\text { ratio }\end{array}$ \\
\hline 2004 & 632501.76 & 54979.65 & -0.0081 & 1.6632 & 89.9692 & 0.1817 \\
\hline 2007 & 2554597.58 & 171320.56 & -0.0014 & 0.055 & 21.153 & 0.1617 \\
\hline 2009 & 5523892.43 & 376717.69 & 0.0027 & 0.1528 & 7.7787 & 0.2093 \\
\hline 2011 & 5853846.93 & 369442.89 & -0.0281 & 0.0579 & 29.3071 & 0.2565 \\
\hline
\end{tabular}

All monetary variables are in USD

The Frontier 4.1 statistical program has been employed to carry out maximum likelihood estimation of the stochastic distance frontier and inefficiency equation simultaneously in a single stage that is known to increase the efficiency of estimates (Coelli, 1996). We begin with estimation of a simple model where the distance function is as specified earlier but the inefficiency equation contains only the two key outreach variables of ALB and WB. The estimation results of translog distance function are provided in the top panel of Table 2. Foremost, it is crucial to examine if at all there exist significant inefficiency in MFI operations demanding frontier analysis. It may be noted that the variance parameter $(\gamma)$ is significant at the $1 \%$ level which implies that inefficiency effects are indeed playing a significant role.

Our interest is in the determinants of inefficiency shown in the lower panel of Table 2. ALB appears to have a strong negative impact on inefficiency with the t-statistic value being -3.052. This implies that those MFIs who lend more to large borrowers on an average are also the more efficient institutions. Therefore lending to the relatively poorer (who are smaller borrowers) appears to reduce efficiency. This suggests that there is a tradeoff between efficiency and outreach. This is similar to the finding of Hermes et al 
(2011). Next, the coefficient of number of women borrowers is negative and significant at the $1 \%$ level. This indicates that lending to women borrowers is associated with higher efficiency of the lending institutions. There exists contradictory evidence in the literature regarding the effect of women clients on MFI performance. Some studies suggest that since women have better repayment rates and lending to them may be less expensive it may improve MFI efficiency (e.g. Armendariz and Morduch, 2005). However, Hermes et al. (2011) find evidence that MFIs that have more women borrowers as clients are less efficient.

Our analysis suggests an inverse relationship between inefficiency and women borrowers suggesting that women borrowers in the Indian microfinance market are more reliable in repaying their obligations and thus enhance efficiency of MFIs. This suggests that there is no tradeoff between efficiency and outreach if targeting women borrowers is considered as a mission of MFIs. In that sense there is no 'mission drift' even for the most efficient institutions. The broad conclusion emerging from the evidence so far is that there is a need to nuance the sustainability-outreach or efficiency-outreach debate. The message we draw depends on the definition of outreach. Women empowerment is one of the key goals of MFI sector in countries like India where women suffer from lack of access to the labour market and face significant challenge in society. In this context, MFIs that are helping women get access to finance are able to do so without compromising on their financial sustainability. Therefore the tradeoff is non-existent in this respect.

Table 2: Estimation of stochastic distance function with inefficiency effects

\begin{tabular}{lll}
\hline \hline Variable & $\begin{array}{l}\text { Estimated } \\
\text { values }\end{array}$ & $\begin{array}{l}\text { Standard } \\
\text { Error }\end{array}$ \\
\hline Stochastic distance function & & \\
\hline Intercept & $18.053^{* * *}$ & 2.122 \\
InNP & 0.333 & 0.306 \\
$\operatorname{In} O E$ & -0.417 & 0.356 \\
$\operatorname{In} F E$ & 0.425 & 0.291 \\
$\ln (F R / N A B)$ & 0.566 & 0.463 \\
$\operatorname{In}(G L P / N A B)$ & $3.435^{* * *}$ & 0.693 \\
$(\operatorname{In} N P)^{2}$ & $-0.050^{* *}$ & 0.023 \\
$(\operatorname{In} N P)(\operatorname{In} O E)$ & 0.035 & 0.041 \\
$(\operatorname{In} N P)(\operatorname{In} F E)$ & 0.028 & 0.037 \\
$(\operatorname{In} O E)^{2}$ & 0.020 & 0.027 \\
$(\operatorname{In} O E)(\operatorname{In} F E)$ & -0.047 & 0.031 \\
$(\operatorname{In} F E)^{2}$ & $-0.022^{* * *}$ & 0.009 \\
$(\operatorname{In}(F R / N A B))^{2}$ & $0.152^{* * *}$ & 0.042
\end{tabular}




\begin{tabular}{|c|c|c|}
\hline$(\ln (F R / N A B))(\ln (G L P / N A B))$ & -0.142 & 0.102 \\
\hline$(\ln (G L P / N A B))^{2}$ & $-0.245^{* * *}$ & 0.099 \\
\hline$(\ln N P)(\ln (F R / N A B))$ & -0.033 & 0.049 \\
\hline$(\ln N P)(\ln (G L P / N A B))$ & $-0.140 * *$ & 0.068 \\
\hline$(\ln O E)(\ln (F R / N A B))$ & -0.004 & 0.062 \\
\hline$(\ln O E)(\operatorname{In}(G L P / N A B))$ & 0.038 & 0.063 \\
\hline$(\ln F E)(\ln (F R / N A B))$ & 0.002 & 0.036 \\
\hline$(\ln F E)(\ln (G L P / N A B))$ & 0.003 & 0.055 \\
\hline$T$ & -0.075 & 0.093 \\
\hline$t^{2}$ & -0.001 & 0.003 \\
\hline$t \ln N P$ & -0.002 & 0.013 \\
\hline $\operatorname{tln} O E$ & -0.011 & 0.013 \\
\hline$T \ln F E$ & $0.020 *$ & 0.011 \\
\hline $\operatorname{tn}(F R / N A B)$ & -0.002 & 0.020 \\
\hline $\operatorname{tn}(G L P / N A B)$ & 0.002 & 0.023 \\
\hline \multicolumn{3}{|l|}{ Inefficiency Model } \\
\hline Intercept & $8.781 * * *$ & 0.547 \\
\hline $\ln A L B$ & $-1.075^{* * *}$ & 0.070 \\
\hline $\ln W B$ & $-0.358 * * *$ & 0.027 \\
\hline \multicolumn{3}{|l|}{ Variance Parameters } \\
\hline$\sigma^{2}$ & $0.042 * * *$ & 0.004 \\
\hline$r$ & $0.569 * * *$ & 0.069 \\
\hline log likelihood & 94.639 & \\
\hline
\end{tabular}

Note: ${ }^{* * *}$ significant at $1 \%,{ }^{* *}$ significant at $5 \%, *$ significant at $10 \%$

Next we repeat the above estimation with different combinations of the inefficiency equation. For the purpose of discussion we present only the inefficiency equation estimates from these different combinations and not the distance function estimates (see Table 3). Model 1 is the same as the simple inefficiency model in Table 1. Model 2 replaces number of women borrowers with the percentage of women borrowers. This is done to study whether the share of women among all the active borrowers is important. The coefficient is negative and significant at the $5 \%$ level confirming that more efficient MFIs have higher share of women borrowers among their clients. Model 3 incorporates time, size, profitability, leverage and age. The key results remain unchanged viz. there is a tradeoff when outreach is defined as lending to the poor (coefficient of ALB is -0.578 and significant at the $1 \%$ level) but the tradeoff disappears when it comes to lending to women (coefficient of WB is -0.249 and significant at the $1 \%$ level). The 
coefficient of time is negative and significant indicating that average MFI efficiency is coming down over the years. This can be attributed to the fallout of the crisis in Andhra Pradesh and the industry has not fully recovered from the effects of the subsequent government action. Size is negative and significant which means that larger MFIs are more efficient suggesting the benefits of scale. Higher profitability and leverage are associated with higher efficiency as shown by the negative and significant coefficients of ROA and DER. Profitable MFIs are the ones that generate more loans and higher revenues while leverage helps MFIs fund their lending activities. The size and leverage results are similar to the findings of Masood and Ahmad (2010). AGE has a positive and significant coefficient suggesting that learning benefits are absent in the MFI sector and older MFIs are less efficient. This is consistent with the findings of Hermes et al (2011). In model 4 when we replace number of women borrowers with its percentage, we lose the significance of this variable and the coefficient of ALB surprisingly turns positive. The results for the control variables (except DER) go through.

In model 5 we examine the possibility of non-linear effects in the way average loan size affects inefficiency. The coefficient of ALB appears to be positive while the coefficient of ALB-square is negative (both are statistically significant). This means there is a concave relationship between inefficiency and ALB indicating that there is a threshold level of average loan size up to which inefficiency would rise. However beyond the threshold average loan size, inefficiency starts declining and efficiency increases. This can be explained by the fact that servicing small loans is costly for any financial institution and scale economies kick in only after the average loan per borrower is of a minimum value. The rest of the results are similar as before. In addition to non-linearity we also study the role of environmental factors using three dummy variables. The only dummy that is statistically significant is the one for legal status indicating that NGOs are less inefficient than other types of MFIs probably because of the less stringent regulation faced by them unlike non banking finance companies that are regulated by the RBI. The dummy variables for regulation and location do not seem to play a significant role in efficiency of MFIs. In model 6 we replace women borrowers by the percentage of women among total borrowers and once again the coefficient is not statistically significant. However the remaining results are similar as before. As robustness checks, we used alternative definitions of some of the variables (such as ROE for profitability, Capital to asset ratio for leverage) but the results remain qualitatively unchanged.

Table 3: Results from estimation of different Inefficiency models

\begin{tabular}{|l|l|l|l|l|l|l|}
\hline $\begin{array}{l}\text { Determinants } \\
\text { of } \\
\text { Inefficiency }\end{array}$ & Model 1 & Model 2 & Model 3 & Model 4 & Model 5 & Model 6 \\
\hline & $\begin{array}{l}8.781 \\
\text { Intercept }\end{array}$ & $\begin{array}{l}3.621 \\
(16.042)\end{array}$ & $\begin{array}{l}12.268 \\
(15.963)\end{array}$ & $\begin{array}{l}6.112 \\
(8.242)\end{array}$ & $\begin{array}{l}3.819 \\
(0.792)\end{array}$ & $\begin{array}{l}7.681 \\
(2.934)\end{array}$ \\
\hline & -1.075 & -0.868 & -0.578 & 0.772 & 4.065 & 1.741 \\
$A L B$ & $(-15.277)$ & $(-3.052)$ & $(-10.686)$ & $(7.334)$ & $(3.162)$ & $(2.187)$ \\
\hline
\end{tabular}




\begin{tabular}{|c|c|c|c|c|c|c|}
\hline ALB-Square & & & & & $\begin{array}{l}-0.476 \\
(-3.868)\end{array}$ & $\begin{array}{l}-0.204 \\
(-2.731)\end{array}$ \\
\hline$W B$ & $\begin{array}{l}-0.358 \\
(-13.132)\end{array}$ & & $\begin{array}{l}-0.249 \\
(-8.038)\end{array}$ & & $\begin{array}{l}-0.256 \\
(-8.178)\end{array}$ & \\
\hline \%WB & & $\begin{array}{l}-0.007 \\
(-1.775)\end{array}$ & & $\begin{array}{l}0.001 \\
(1.492)\end{array}$ & & $\begin{array}{l}0.001 \\
(1.593)\end{array}$ \\
\hline$T$ & & & $\begin{array}{l}-0.016 \\
(-1.735)\end{array}$ & $\begin{array}{l}-0.192 \\
(-4.768)\end{array}$ & $\begin{array}{l}-0.281 \\
(-1.613)\end{array}$ & $\begin{array}{l}-0.279 \\
(-3.977)\end{array}$ \\
\hline AST & & & $\begin{array}{l}-0.325 \\
(-7.429)\end{array}$ & $\begin{array}{l}-0.425 \\
(-206.880)\end{array}$ & $\begin{array}{l}-0.342 \\
(-7.551)\end{array}$ & $\begin{array}{l}-0.505 \\
(-13.100)\end{array}$ \\
\hline$R O A$ & & & $\begin{array}{l}-0.996 \\
(-8.722)\end{array}$ & $\begin{array}{l}-1.395 \\
(-13.359)\end{array}$ & $\begin{array}{l}-0.927 \\
(-8.376)\end{array}$ & $\begin{array}{l}-1.190 \\
(-9.699)\end{array}$ \\
\hline$D E R$ & & & $\begin{array}{l}0.000 \\
(-8.722)\end{array}$ & $\begin{array}{l}0.000 \\
(0.800)\end{array}$ & $\begin{array}{l}0.000 \\
(-0.621)\end{array}$ & $\begin{array}{l}0.000 \\
(0.921)\end{array}$ \\
\hline$A G E$ & & & $\begin{array}{l}0.002 \\
(1.931)\end{array}$ & $\begin{array}{l}0.002 \\
(1.413)\end{array}$ & $\begin{array}{l}0.004 \\
(2.692)\end{array}$ & $\begin{array}{l}0.003 \\
(2.442)\end{array}$ \\
\hline DUM (RGL) & & & & & $\begin{array}{l}-0.007 \\
(-0.260)\end{array}$ & $\begin{array}{l}-0.002 \\
(-0.072)\end{array}$ \\
\hline DUM (LCN) & & & & & $\begin{array}{l}-0.019 \\
(-1.136)\end{array}$ & $\begin{array}{l}-0.014 \\
(-0.669)\end{array}$ \\
\hline DUM (LS) & & & & & $\begin{array}{l}-0.045 \\
(-1.773)\end{array}$ & $\begin{array}{l}-0.025 \\
(-0.909)\end{array}$ \\
\hline
\end{tabular}

Notes: Numbers in brackets are t-statistics; ${ }^{* * *}$ significant at $1 \%,{ }^{* *}$ significant at $5 \%, *$ significant at $10 \%$

Finally we take a look at the average efficiency scores in the Indian MFI industry. The efficiency values are estimated based on model 6 (other models generate very similar results). Year-wise averages along with standard deviations are plotted in Chart 1. The mean efficiency stood at 0.03 in 2004 that substantially improved over the years to reach 0.31 in 2011. In spite of the improvement the numbers indicate that there are significant inefficiencies present in the Indian MFI industry. 


\section{Chart 1: Trend in average efficiency of Indian MFls}

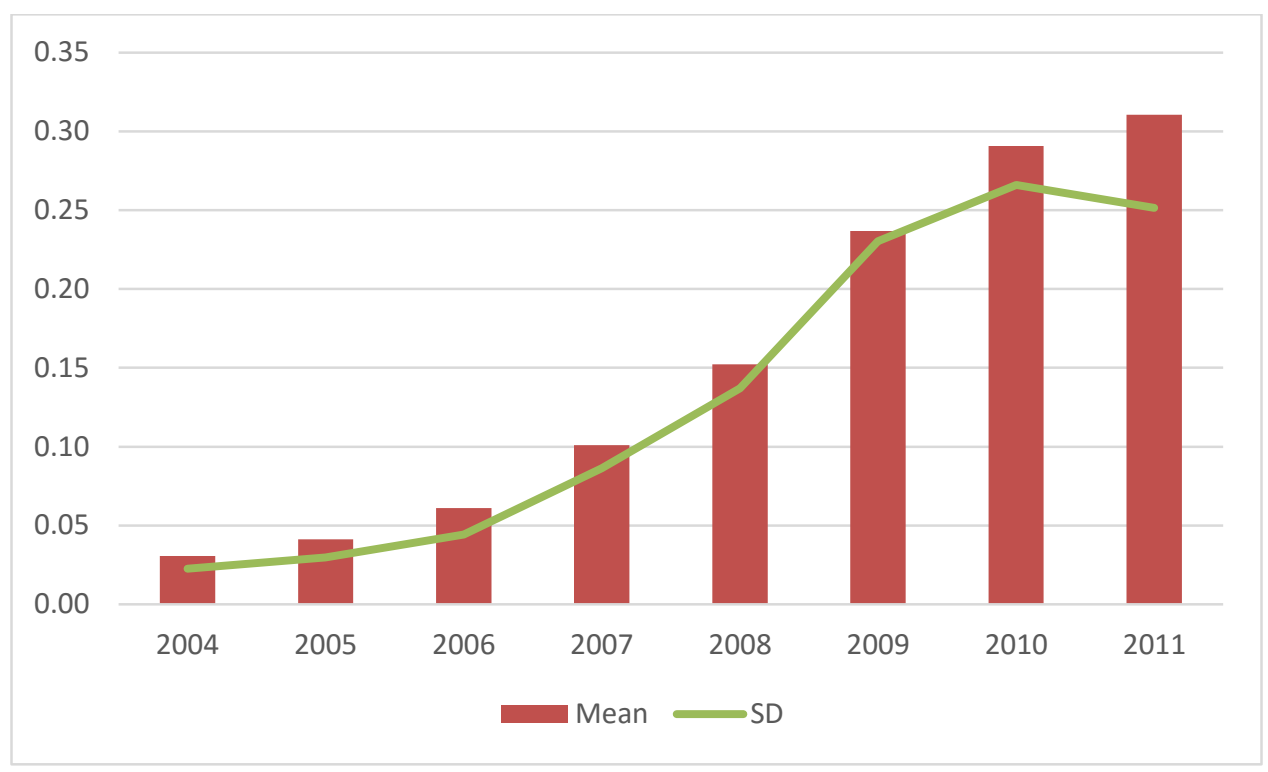

The average efficiency scores of top and bottom MFIs are tabulated in Table 4. FFSL is found to be the most efficient MFI among the lot. This MFI started operations in Andhra Pradesh but soon ventured into neighbouring states of Tamil Nadu and Karnataka. FFSL is followed by BASIX which was founded by Vijay Mahajan known as the pioneer of Microfinance industry in India. BASIX has operations spread across 17 states in India. The next most efficient institutions are the Karnataka based SKDRDP and the Rajasthan based Pustikar. The poor performing MFIs constitute the Tamil Nadu based CCFID and Disha that operates out of Uttar Pradesh and Uttaranchal.

Table 4: Average Efficiency Scores: Best and worst MFls

Top ten MFIs

\begin{tabular}{lr}
\hline MFI & $\begin{array}{l}\text { Average } \\
\text { Efficiency }\end{array}$ \\
\hline FFSL & 0.305082 \\
BASIX & 0.341546 \\
SKDRDP & 0.418494 \\
Pustikar & 0.425984 \\
AML & 0.44328 \\
Bandhan & 0.449614 \\
Spandana & 0.459968 \\
SHARE & 0.487017 \\
SKS & 0.499204 \\
Equitas & 0.553604 \\
\hline
\end{tabular}




\begin{tabular}{ll} 
Bottom ten MFIs & \\
\hline MFI & $\begin{array}{l}\text { Average } \\
\text { Efficiency }\end{array}$ \\
\hline CCFID & 0.025396 \\
Disha & 0.031298 \\
BJS & 0.037629 \\
NCS & 0.040098 \\
NBJK & 0.042328 \\
GLOW & 0.050756 \\
WSE & 0.051317 \\
BWDC & 0.052772 \\
Mahashakti & 0.054778 \\
NEED & 0.060681 \\
\hline
\end{tabular}

\section{Conclusion}

MFIs are crucial in rendering basic banking services to underprivileged rural poor and empowering them (especially women) towards self-reliance. By virtue of micro level operations, MFIs have the benefit of through assessment and close monitoring of individual/ group behavior unlike banks who service a much larger and heterogeneous population. Across the globe MFls have been operating with varying degree of success and India has become the largest microfinance market in the world. In this context, we examine operating efficiency of MFIs in the Indian scenario. The study utilizes stochastic distance function methodology to incorporate multiple outputs simultaneously for an unbalanced panel of $75 \mathrm{MFIs}$ from 2004 to 2011. The methodology has the advantage that other than handling multiple outputs it also allows testing of hypothesis. We find that indeed inefficiency effects are significant with deteriorating trend for the last couple of years. Average loan balance per borrower and women borrowers have significant effect on inefficiency. We find that while lending to poorer clients increases inefficiency, targeting the women among the clients enhances efficiency. This leads us to believe that the efficiency-outreach tradeoff is more nuanced than has been presented in the literature. Indian MFIs exhibit a tradeoff when it comes to reaching out to the poor but there is no such tradeoff when it comes to women empowerment.

It is clear that MFIs would strive to lend to women as it helps them to fulfill one of their missions without compromising on financial sustainability. However lending to the poorer clients does not generate financial benefits. Zeller and Johansson (2006) argue that it is not necessarily a cause for concern. If MFIs strive for financial sustainability and hence lend to better off borrowers, they may end up helping poverty alleviation by improving economic conditions at the local and national levels. The effects of this economic growth would ultimately benefit the poor and thereby outweigh any neglect of the poor in loan disbursal. While this may well be true in the long run, greater efforts need to be simultaneously undertaken by the government to ensure that lending to the poor can also become an attractive proposition. This can be done by the policy makers by various ways such as providing discounted refinancing facilities for small size loans, helping the poor directly through cash transfers or by generating employment and entrepreneurship opportunities for the poor in the local communities. 


\section{$\underline{\text { References }}$}

Ahlin, C., Lin, J., \& Maio, M. (2011). Where does microfinance flourish? Microfinance institution performance in macroeconomic context. Journal of Development Economics, 95(2), 105-120.

Armendariz de Aghion, B. and Morduch, J. (2005), The Economics of Microfinance (Cambridge and London: MIT Press, 2005).

Battese, G. E., \& Coelli, T. J. (1992). Frontier production functions, technical efficiency and panel data: with application to paddy farmers in India. Journal of productivity analysis, 3(1-2), 153-169.

Benston, G. J. (1965). Branch banking and economies of scale. The Journal of Finance, 20(2), 312-331.

Berger, A. N., \& Humphrey, D. B. (1992). Measurement and efficiency issues in commercial banking. In Output measurement in the service sectors (pp. 245-300). University of Chicago Press.

Chakrabarty, K.C., (2013), Financial Inclusion in India: Journey So Far and Way Forward. Keynote address delivered by Dr. K.C. Chakrabarty, Deputy Governor, Reserve Bank of India at Finance Inclusion Conclave, New Delhi, September, 2013

Coelli, T.J., (1996).A Guide to FRONTIER version 4.1: A Computer Program for Stochastic Frontier Production and Cost Function Estimation. Department of Econometrics, University of New England, Armidale, NSW, Australia.

Cuesta, R.A. and Orea, L. (2002). Mergers and technical efficiency in Spanish savings banks: A stochastic distance function approach, Journal of Banking and Finance, Vol. 26, pp. 2231-2247.

Das, A. and Kumbhakar, S.C., (2012). Productivity and efficiency dynamics in Indian banking: An input distance function approach incorporating quality of inputs and outputs, Journal of Applied Econometrics, Vol. 27, pp. 205-234.

Feldstein, M. and Horioka, C. (1980), Domestic saving and international capital flows, Economic Journal, Vol. 90, pp. 314-29.

Fernando, N. A. (2004). Micro Success Story?: Transformation of Nongovernment Organizations Into Regulated Financial Institutions. Asian Development Bank.

Ferrari, A. (2006). The internal market and hospital efficiency: a stochastic distance function approach, Applied Economics, 38(18), 2121-2130.

Ford, R. and Poret, P. (1991), Infrastructure and private-sector productivity, Economic Studies, Vol. 17, pp. 63-89.

Haq, M., Skully, M., \& Pathan, S. (2010). Efficiency of microfinance institutions: a data envelopment analysis. Asia-Pacific Financial Markets, 17(1), 63-97.

Hermes, N., \& Lensink, R. (2011). Microfinance: Its Impact, Outreach, and Sustainability. World Development, 39(6), 875-881.

Hermes, N., Lensink, R., \& Meesters, A. (2011). Outreach and efficiency of microfinance institutions. World Development, 39(6), 938-948. 
Irz, X., \& Thirtle, C. (2004). Dual Technological Development in Botswana Agriculture: A Stochastic Input Distance Function Approach. Journal of Agricultural Economics, 55(3), 455-478.

Kumar, N. (2012). An empirical analysis of financial inclusion across population groups in India. The IUP Journal of Bank Management, 10(1), 97-111.

Kumar, N. (2013). Financial inclusion and its determinants: evidence from India. Journal of Financial Economic Policy, 5(1), 4-19.

Levine, R. (2002), Bank-based or market-based financial systems: which is better?, Journal of Financial Intermediation, Vol. 11, pp. 398-428.

Mader, P. (2013), Rise and Fall of Microfinance in India: The Andhra Pradesh Crisis in Perspective, Strategic Change, Vol. 22, Issue 1-2, pages 47-66.

Masood, T., \& Ahmad, M. (2010).Technical Efficiency of Microfinance Institutions in India-A Stochastic Frontier Approach. MPRA Paper No 25454.

Obstfeld, M. (1994), Risk-taking, global diversification, and growth, American Economic Review, Vol. 84, pp. 10-29.

Robinson, M. S. (2002). The Microfinance Revolution: Lessons from Indonesia. Vol. 2. World Bank Publications.

Servin, R., Lensink, R., \& van den Berg, M. (2012). Ownership and technical efficiency of microfinance institutions: Empirical evidence from Latin America. Journal of Banking \& Finance, 36(7), 2136-2144.

Shaw, E.S. (1973), Financial Deepening in Economic Growth, Oxford University Press, New York, NY.

Simar, L., \& Wilson, P.W. (2007). Estimation and inference in two-stage, semi-parametric models of production processes, Journal of Econometrics, Vol. 136(1), pp. 31-64.

Subbarao, D. (2009), Financial inclusion challenges and opportunities, Speech Delivered by Dr Duvvuri Subbarao, Governor, Reserve Bank of India, Bankers' club, Kolkata, December 9.

Tchakoute-Tchuigoua, H. (2010). Is there a difference in performance by the legal status of microfinance institutions?. The Quarterly Review of Economics and Finance, 50(4), 436-442.

Zeller, M, and J. Johannson. 2006. "Is There a Difference in Poverty Outreach by Type of Microfinance Institution? The Case of Peru and Bangladesh," Paper presented at the Global Conference on Access to Finance: Building Inclusive Financial Systems, World Bank and Brookings Institution, Washington D.C., May 30-31. 